\title{
EFFECT OF COMPLEMENTARY FEEDING ON STUNTING AND ANAEMIA IN TODDLERS IN SIDOARJO, EAST JAVA
}

\author{
Lailatul Khusnul Rizki, Esty Puji Rahayu,
}

Universitas Nahdlatul Ulama Surabaya

\begin{abstract}
Background: Stunting is a chronic malnutritional problem which has the risk of developing degenerative diseases and delay the intelligence of children in the future. Anaemia in children is also a health problem in developing countries. This study aimed to examine the effect of complementary feeding on stunting and anaemia in toddlers in Sidoarjo, East Java.

Subjects and Method: A cross-sectional study was conducted at Integrated Health Post, Community Health Center Porong, Sidoarjo, East Java. A sample of 99 toddlers under three years of age was selected for this study. The dependent variables were stunting and anemia. The height of the toddlers was measured by microtoise. The hemoglobin level was measured by digital hemoglobin test. The independent variable was supplementary feeding. The data were analyzed by chi-square.

Results: Supplementary feeding associated with childhood stunting, and it was statistically significant $(\mathrm{p}=0.001)$. Supplementary feeding associated with anemia, and it was statistically significant $(\mathrm{p}=0.021)$.
\end{abstract}

Conclusion: Supplementary feeding associates with childhood stunting and anemia, and it is statistically significant.

Keywords: supplementary feeding, stunting, anemia

\section{Correspondence:}

Lailatul Khusnul Rizki. Universitas Nahdlatul Ulama Surabaya. Jl. SMEA No.57, Surabaya, East Java. Email: lailarizki91@gmail.com. Mobile: +6282231660854. 